\title{
HUBUNGAN DURASI BERMAIN GADGED (GAME EDUKASI) DENGAN TINGKAT PERKEMBANGAN ANAK USIA 4-6 TAHUN DI TK DAHLIA DARMAJI
}

\author{
Baiq Larasati Septami ${ }^{1}$, Lalu Wiresanta ${ }^{2}$, Beti Haerani ${ }^{3}$ \\ 1,2,3 Departemen Keperawatan, Fakultas Kesehatan,Universitas Qamarul Huda \\ Bagu,Lombok, Indonesia
}

Email: larasatiseptami@gmail.com

\begin{abstract}
ABSTRAK
Perkembangan gadged (game edukasi) yang sangat pesat, memberikan dampak terhadap tingkat perkembangan anak karena anak yang sering bermain gadged (game edukasi) akan mengalami keterlambatan pada tingkat perkembangannya. Tujuan penelitian untuk mengetahui hubungan durasi bermain gadged (game edukasi) dengan tingkat perkembangan anak usia 4-6 tahun di TK Dahlia Darmaji. Desain penelitian cross sectional. Populasi 51 anak TK Dahlia Darmaji usia 4-6 tahun. Sampel 45 responden dengan metode total sampling. Variabel independen yaitu durasi bermain gadged (game edukasi) dan variabel dependen yaitu tingkat perkembangan anak usia 46 tahun. Diukur dengan kuesioner dan DDST anak. Tehnik analisa data menggunakan uji chi-square $\alpha=0,05$.

Hasil penelitian menunjukkan bahwa durasi bermain gadged (game edukasi) sering 21 responden (46,7\%), dan tingkat perkembangan anak usia 4-6 tahun terlambat 34 responden $(75,6 \%)$. Hasi uji ch-square $\alpha=0,05$ didapatkan $p=0,000<0,05$ sehingga H1 diterima, artinya ada hubungan durasi bermain gadged (game edukasi) dengan tingkat perkembangan anak usia 4-6 tahun. Diharapakan orang tua dapat membatasi anak dalam durasi bermain gadged (game edukasi) dan mengawasi kegiatan yang dilakukan anak saaat bermain gadged.
\end{abstract}

Kata kunci : Gadged (game edukasi), Tingkat Perkembangan, Anak 


\title{
RELATIONSHIP DURATION OF PLAYING GADGED (EDUCATIONAL GAME) WITH CHILDREN'S DEVELOPMENT LEVEL AGED 4-6 YEARS OLD AT KINDERGARTEN SCHOOL OF DAHLIA DARMAJI
}

\begin{abstract}
The development of gadgeds (educational game) is very rapid, giving an impact on children's development level because children who often play gadged (educational game) will experience retardment at his development level. The aim of the study to determine the relations beetween Relationship Duration Playing Gadged (educational game) With Children's Development Level Aged 4-6 Years Old At Kindergarten School of Dahlia Darmaji. Cross sectional research design. The population were 51 kindergaeden children of Dahlia Darmaji aged 4-6 years old. Sample were 45 respondents with total sampling method. The independet variable was relationship duration playing gadged (educational game) and the dependent variable was the children's development level aged 4-6 years old. It measured by questionnaire and children DDST. Data analysis technique used chi-square test $\alpha=0,05$.

The results showed that duration of playing gadged (educational game) often were 21 respondent (46,7\%), and children's development level aged 4-6 years old late were 34 respondent $(75,6 \%)$. Chi-square test results $\alpha=0,05$ obtained $p=0,000<0,05$ so $H 1$ was accepted, it meant there was relationship duration of playing gadged (educational game) with children's development level aged 4-6 years old. It is expected that parents can limit children in the duration of playing gadged (educational game) and oversee the activities carried out on children while playing gadged.
\end{abstract}

Keywords : Gadged (educational game), Development Level, Children 


\section{PENDAHULUAN}

World Health Organization (WHO) melaporkan bahwa 5-25\% anak usia prasekolah menderita gangguan perkembangan. Berbagai masalah perkembangan anak seperti keterlambatan motorik, bahasa dan perilaku sosial dalam beberapa tahun terakhir ini semakin meningkat.

Dalam survey yang dilakukan oleh the Asianparent Insights (2014), pada lingkup studi kawasan Asia Tenggara dengan melibatkan setidaknya 2.417 orang tua yang memiliki gadged dan anak dengan usia 3-8 tahun pada lima negara yakni Singapura, Thailand, Philipina, Malaysia dan Indonesia. Dengan sejumlah sampel orang tua tersebut, diperoleh 3.917 sampel anak dengan usia 3-8 tahun. Dari 98\% responden anak usia 3-8 tahun pengguna gadged tersebut $67 \%$ diantaranya meggunakan gadged milik orang tua mereka, $18 \%$ lainnya menggunakan gadged milik saudara dan $14 \%$ sisanya menggunakan gadged milik sendiri. Angka kejadian masalah perkembangan pada anak di Indonesia antara 13-18\%. Sekitar 9,5\% sampai $14,2 \%$ anak prasekolah memiliki masalah sosial emosional yang berdampak negatif terhadap perkembangan dan kesiapan sekolahnya (Brauner \& Stephens , 2016).

Di Provinsi Nusa Tenggara barat sendiri jumlah balita dan anak usia prasekolah yaitu $8,60 \%$ dari $100 \%$ jumlah seluruh popolasi atau sekitar 414.265 jiwa dari 4.813.948 jiwa, dengan angka yang tertinggi berada di kabupaten Lombok Timur sejumalh 104.602 jiwa dan yang terendah di Kota Bima yaitu sejumlah 14.826 jiwa. Gadged adalah sebuah istilah dalam bahasa inggris yaitu perangkat elektronik kecil yang memiliki tujuan dan fungsi khusus untuk mengunduh informasi-informasi terbaru dengan berbagai teknologi maupun fitur terbaru, sehingga membuat hidup manusia menjadi lebih praktis. Gadged sendiri dapat berupa komputer atau laptop, tablet pc, video game dan juga telepon seluler atau smartphone (Indrawan, 2014).

Perkembangan adalah perubahan individu baik itu fisik maupun psikis yang berlangsung sepanjang rentang hidup. Anak memiliki suatu ciri yang khas yaitu selalu tumbuh dan berkembang sejak lahir sampai berakhirnya masa remaja (Hidayat 2005). Perkembangan adalah peningkatan kemampuan dalam hal struktur dan fungsi tubuh yang lebih kompleks. Perkembangan memiliki pola yang teratur dan dapat diprediksi, yang merupakan hasil dari proses pematangan (Nugroho, 2009).

Anak prasekolah adalah anak yang berusia antara 3-6 tahun, dalam usia ini anak umumnya mengikuti program anak (3-5 tahun) dan kelompok bermain (Usia 3 Tahun), sedangkan pada usia 4-6 tahun biasanya mereka mengikuti program Taman KanakKanak (Patmonedowo, 2008). Anak usia dini adalah anak yang berada pada usia 0-8 tahun. Menurut Beichler dan Snowman (Yulianti, 2010), anak usia dini adalah anak yang berusia antara 3-6 tahun. 
Indonesia kini bahkan telah menjadi salah satu negara dengan pengguna Facebook dan Twitter terbesar didunia, yang penggunanya masing-masing mencapai 51 juta dan 19.5 juta orang. Ini adalah kenikmatan penduduk dunia abad ke-21. Jarak dan waktu bagaikan terbunuh oleh kemajuan teknologi informasi semacam ini. Di Indonesia, bila di tahun 2012 hanya 27 $\%$ anak di usia balita yang menggunakan gadget, di tahun 2014, jumlahnya meningkat hingga $73 \%$. Dan $29 \%$ di antaranya, sudah memiliki tablet pribadi pemberian orang tua (Wijanarko, 2016).

Penelitian yang dilakukan oleh Tria Puspita Sari \& Amy Asma Mitsalia (2016) tentang pengaruh penggunaan gadged terhadap personal sosial anak usia pra sekolah di TKIT Al-Mukmin. Hasil analisis yang didapatkan diketahui bahwa dalam kelompok kasus, anak yang sering memainkan gadgetnya sebanyak 18 anak (95\%), berbeda dengan anak pada kelompok kontrol dimana anak yang sering memainkan gadget hanya 4 anak (21\%) dan lebih mayoritas jarang memainkan gadgetnya yaitu sebanyak 15 anak (79\%). Namun secara keseluruhan anak yang sering memainkan gadget lebih dominan yaitu sebanyak 22 anak (58\%) daripada anak yang jarang bermain gadget yang hanya 16 anak (42\%).

Berdasarkan uraian di atas peneliti tertarik melakukan penelitian dengan judul "Hubungan durasi bermain gadged (game edukasi) dengan tingkat perkembangan anak usia 4-6 tahun di TK Dahlia Darmaji tahun 2019"'

Tujuan penelitian ini adalah untuk mengetahui Hubungan durasi bermain gadged (game edukasi) dengan tingkat perkembangan anak usia 4-6 tahun di TK Dahlia Darmaji tahun 2019.

\section{METODE PENELITIAN}

Penelitian ini menggunakan jenis penelitian survey analitik dengan pendekatan cross-sectional, karena peneliti bermaksud untuk mengidentifikasi apakah ada hubungan bermain gadged (game edukasi) dengan tingat perkembangan anak usia 4-6 tahun.

Popolasi dalam penelitian ini adalah adalah semua siswa/siswi TK Dahlia Dramaji. Jumlah seluruh siswa/siswi kelas A \& B adalah 51 orang. Sampel dalam penelitian ini adalah 45 orang anak

Instrumen yang digunakan dalam penelitian ini adalah kuesioner dan DDST, dimana kuesioner yang digunakan telah dilakukan uji validitas dan reabilitas oleh peneliti langsung, sedangkan untuk DDST merupakan instrument yang sudah valid.

HASIL DAN PEMBAHASAN

Karakteristik responden Usia

Tabel 1 anak responden

\begin{tabular}{|c|c|c|c|}
\hline No & Umur & Frekuensi & Presentase $(\%)$ \\
\hline 1 & 4 tahun & 15 & 33,3 \\
\hline
\end{tabular}




\begin{tabular}{|c|c|c|c|}
\hline 2 & 5 tahun & 23 & 51,1 \\
3 & 6 tahun & 7 & 15,6 \\
\hline & Jumlah & 45 & 100 \\
\hline
\end{tabular}

Berdasarkan tabel 1 menunjukkan bahwa sebagian besar dari responden berumur 5 tahun sejumlah 23 orang
(51,1\%), umur 4 tahun sejumlah 15 orang $(33,3 \%)$ dan umur 6 tahun sejumlah 7 orang $(15,6 \%)$.

\section{Jenis kelamin}

Tabel 2 jenis kelamin anak responden

\begin{tabular}{l|c|c|c|c|}
\hline No & $\begin{array}{c}\text { Jenis kelamin } \\
\text { anak }\end{array}$ & Frekuensi & $\begin{array}{c}\text { Presentase } \\
(\%)\end{array}$ \\
\hline 1 & Laki-Laki & 30 & 66,7 \\
\\
2 & Perempuan & 15 & 33.3 \\
\hline & Jumlah & 45 & 100 \\
Berdasarkan & tabel 2 & orang $(66,7 \%)$ dan sebagian \\
menunjukkan bahwa sebagian & & kecil berjenis kelamin \\
besar dari responden berjenis & & Perempuan sejumlah 15 orang \\
kelamin Laki-Laki sejumlah 30 & & $(33,3 \%)$.
\end{tabular}

\section{Pendidikan}

Tabel 3 pendidikan orang tua

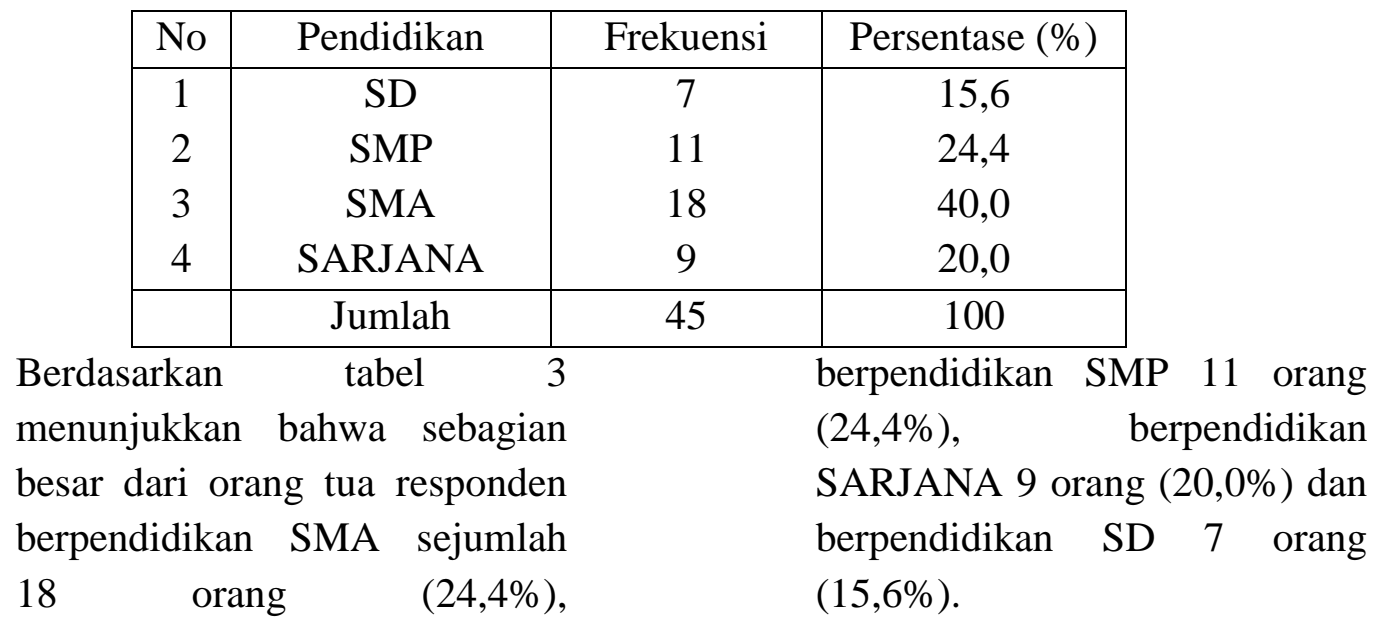

Pekerjaan

Tabel 4 pekerjaan orang tua

\begin{tabular}{|l|l|l|l|}
\hline No & Pekerjaaan & Frekuensi & Persentase (\%) \\
\hline
\end{tabular}




\begin{tabular}{|c|c|c|c|}
\hline 1 & IRT & 26 & 57,8 \\
2 & TANI & 1 & 2,2 \\
3 & SWASTA & 14 & 31,1 \\
4 & PNS & 4 & 8,9 \\
\hline & Jumlah & 45 & 100 \\
\hline
\end{tabular}

Berdasarkan tabel 4 menunjukkan bahwa sebagian besar dari orang tua responden bekerja sebagai IRT sejumlah 26 orang $(57,8 \%)$, bekerja sebagai
SWASTA sejumlah 14 orang $(31,1 \%)$, bekerja sebagai PNS sejumlah 4 orang $(8,9 \%)$ dan bekerja sebagai TANI sejumlah 1 orang $(2,2 \%)$.

\section{Durasi bermanin gadged (game edukasi )}

Tabel 5 Durasi bermanin gadged

\begin{tabular}{|c|l|c|c|}
\hline No & \multicolumn{1}{|c|}{ Durasi } & Frekuensi & Persentase (\%) \\
\hline 1 & Sangat Jarang & 7 & 15,6 \\
2 & Jarang & 15 & 33,3 \\
3 & Sering & 21 & 46,7 \\
4 & Sangat Sering & 2 & 4,4 \\
\hline & Jumlah & 45 & 100 \\
\hline
\end{tabular}

Berdasarkan tabel 5 menunjukkan bahwa sebagian besar anak sering menggunakan gadged (game edukasi) sejumlah 21 orang $(46,7 \%)$, anak yang jarang menggunakan gadged (game edukasi) sejumlah 15 orang $(33,3 \%)$, anak yang sangat jarang menggunakan gadged (game edukasi) sejumlah 7 orang $(15,6 \%)$ dan anak yang sangat sering menggunakan gadged (game edukasi) sejumlah 2 orang $(4,4 \%)$.

\section{Tingkat perkembangan}

\section{Tabel 6 tingkat perkembangan anak}

\begin{tabular}{|c|c|c|c|}
\hline No & Perkembangan & Frekuensi & Presentase $(\%)$ \\
\hline 1 & Normal & 11 & 24,4 \\
2 & Terlambat & 34 & 75,6 \\
\hline & Jumlah & 45 & 100 \\
\hline
\end{tabular}

Berdasarkan tabel 6 menunjukkan bahwa sebagian besar tingkat perkembangan anak TK Dahlia Darmaji adalah terlambat sejumlah 34 orang $(75,6 \%)$ dan yang mengalami tingkat perkembangan normal sejumlah 11 orang $(24,4 \%)$. 
Tabel 7 hubungan durasi bermain gadged (game edukasi) dengan tingkat perkembangan anak usia 4-6 tahun di TK Dahlia Darmaji.

\begin{tabular}{|l|c|c|c|c|c|c|}
\hline \multirow{2}{*}{$\begin{array}{c}\text { Durasi } \\
\text { bermain } \\
\text { gadged }\end{array}$} & \multicolumn{5}{|c|}{ Tingkat Perkembangan } \\
\cline { 2 - 7 } & \multicolumn{2}{|c|}{ Normal } & \multicolumn{2}{c|}{ Terlambat } & \multicolumn{2}{c|}{ Total } \\
& $\begin{array}{c}\text { Frekue } \\
\text { nsi }\end{array}$ & Persentase & $\begin{array}{c}\text { Frekue } \\
\text { nsi }\end{array}$ & Persentase & N & $\%$ \\
\hline Sangat Sering & 0 & 0 & 2 & 4,4 & 2 & 4,4 \\
Sering & 6 & 13,5 & 15 & 33,4 & 21 & 46,6 \\
Jarang & 3 & 6,6 & 12 & 26,6 & 15 & 33,5 \\
Sangat Jarang & 2 & 4,4 & 5 & 11,1 & 7 & 15,5 \\
Jumlah & 11 & 24,5 & 34 & 75,5 & 45 & 100 \\
\hline Hasil SPSS & $\mathrm{p}=0,000$ & \multicolumn{5}{|c|}{$\alpha=0,05$} \\
\hline
\end{tabular}

Berdasarkan tabel 7 dapat diketahui bahwa sebagian besar dari responden dengan jumlah $21(46,6 \%)$ responden dimana 15 responden $(33,3 \%)$ sering bermain gadged (game edukasi) dan mengalami tingkat perkembangan terlambat, jumlahnya lebih banyak dari daripada yang sering bermain gadged (game edukasi) dan mengalami tigkat perkembangan normal yaitu sebanyak 6 responden (13,3\%). Sebagian responden jarang bermain gadged (game edukasi) dan mengalami perkembangan terlambat sebanyak 12 responden $(26,6 \%)$ dan yang mengalami perkembangan normal sebanyak 3 responden $(6,6 \%)$.Sebagian kecil responden sangat jarang bermain gadged (game edukasi) dan mengalami perkembangan normal yaitu sebanyak 2 responden $(4,4 \%)$ sedangkan yang mengalami perkembangan terlambat sebanyak 5 responden $(11,1 \%)$, dan responden yang sangat sering menggunakan gadged (game edukasi) dengan tingkat perkembangan terlambat sebanyak 2 responden $(4,4 \%)$.

Uji chi-square $\alpha=0,05$ antara variabel durasi bermain gadged (game edukasi) dengan tingkat perkembangan anak anak usia 46 tahun di TK Dahlia Darmaji tahun 2019 didapatkan niali $\mathrm{p}=0.000<0,05$. Hasil tersebut kurang dari taraf signifikan yang digunakan yaitu $\mathrm{p}=0,05$, sehingga $\mathrm{H} 1$ diterima $\mathrm{H} 0$ ditolak yang berarti ada hubungan durasi bermain gadged (game edukasi) dengan ingkat perkembangan anak usia 4-6 tahun di TK Dahlia Darmaji. 


\section{KESIMPULAN}

Kesimpulan dari penelitian ini adalah :

1. Hubungan durasi bermain gadged (game edukasi) dengan tingkat perkembangan anak usia 4-6 tahun di TK Dahlia Darmaji cenderung ke arah negatif yaitu sebanyak (46,6\%). Hal ini disebabkan karena dari gadged (game edukasi) anak lebih sering bermain game dan menonton youtube dan jarang berinteraksi dengan orang lain disekitar lingkungannya.

2. Selain dampak negatif gadged (game edukasi) memiliki dampak positif bagi anak yaitu sebanyak $(15,5 \%)$. Hal ini disebabkan karena gadged (game edukasi) anak dapat mengikuti pelajaran seperti menghafal lagu-lagu anak, memudahkan anak mengingat warna, belajar mengenal huruf dan sebagainya.

3. Ada hubungan yang signifikan antara durasi bermain gadged (game edukasi) dengan tingkat perkembangan anak usia 4-6 tahun di TK Dahlia Darmaji. Dibuktikan dengan hasil uji statistik menggunakan pengujian ChiSquare. Pada analisis Chi-Square, Ho ditolak dan Ha diterima.

\section{UCAPAN TERIMAKASIH}

Pada kesempatan ini, peneliti ingin mengucapkan terima kasih kepada berbagai pihak yang telah membantu mewejudkan penelitian ini :
1. Ketua Universitas Qamarul Huda Badaruddin (UNIQHBA) Bagu

2. Prodi S1 Keperawatan

3. Dosen pembimbing dalam penelitian ini

\section{DAFTAR PUSTAKA}

Iswidharmanjaya Derry dan Beranda Agency. 2014. Bila si kecil bermain gadged. Yogyakarta : Bisakimia.

Hapsari Iriani Indri,.M.Psi.2016. Psikologi Perkembangan anak. Kembangan - Jakarta Barat : PT.Indeks.

Wijanarko Jarot. 2016. Pengaruh Pemakaian Gadged dan Perilaku Anak, terhadap kemampuan anak Taman Kanak-kanak Happy Holy Kids. Skripsi. Jakarta : Universitas Terbuka.

Pebriana Putri Hana.2017. Analisis penggunaan gadged terhadap kemampuan interaksi sosial pada anak usia dini. Jurnal pendidikan anak usia dini.1(1) : 1-11.

Elfiadi. 2016. Bermain dan Permainan bagi anak usia dini. Artikel. Aceh : $\quad$ STAIN Malikussaleh Lhokseumawe.

Sari Tria Puspita dan Amy Asma Mitsalia. 2016. Pengaruh penggunaan gadged terhadap personal sosial anak usia prasekolah. Jurnal pendidikan anak usia prasekolah. 13(2) : 7278.

Setianingsih. Amila Wahyuni dan Fitriana Noor Khayati.2018. Dampak penggunaan gadged 
pada anak usia prasekolah dapat meningkatkan resiko gangguan pemusatan perhatian dan hiperaktivitas. Jurnal kesehatan. XVI(2) : 191-205.

Pratiwi Wiwik. 2017. Konsep bermain pada anak usia dini. Jurnal pendidikan anak usia dini.5(2) : 106-117.

Nailirohmah. 2016. Bermain dan pemanfaatannya dalam perkembangan anak usia dini. Jurnal Tarbawi.13(2) : 28-34.

Chusna Puji Asmaul. 2017. Pengaruh media gadged pada perkembangan karakter anak. Jurnal media komunikasi sosial keagamaan.17(2) : 26-117.

Chikmah Adevia Maulidya dan Desy Fitrianingsih.2018. Pengaruh durasi penggunaan gadged terhadap masalah mental emosional anak pra sekolah. Jurnal siklus.7(2) : 295-299.

Ardianto Asep. 2017. Bermain sebagai sarana pengembangan kreativitas anak usia dini. Jurnal jendela olahraga.2(2) : 35-39.

Katharina Telly. 2016. Hubungan antara pengetahuan ibu dengan sikap terhadap tumbuh kembang anak. Jurnal kebidanan.6(2) : 134141.
Amini Mukti,S.Pd,M.Pd. 2003. Hakikat anak usia dini. Modul.

M. Hafiz Al-Ayouby. Dampak penggunaan gadged pada anak usia dini. Skripsi. Bandar Lampung : Universitas Lampung.

Sulis Tri Oktaviani Santoso. 2014. Perkembangan teknologi handphone. Artikel.

Maulida Hidayahti. 2013. Menelisik Pengaruh Penggunaan Aplikasi Gadget Terhadap Perkembangan Psikologis Anak Usia Dini. Jurnal Ilmiah Teknologi Pendidikan 2013. Semanrang : FKIP Universitas Negeri Semarang.

Delima R.,N.K. Arianti dan B Pramudyawardani. (2015). Identifikasi Kebutuhan Pengguna Untuk Aplikasi Permainan Edukasi Bagi Anak Usia 4 sampai 6 Tahun. Jurnal Teknik Informatika dan Sistem Informasi 1(1) : 4-8.

Fadilah, Ahmad. 2011. "Pengaruh Penggunaan Alat Komunikasi Handphone (Hp) Terhadap Aktivitas Belajar Siswa Smp Negeri 66 Jakarta Selatan. 